\title{
Analysis of the Effect of an Installation of a Single Tuned Passive Filter on Harmonics and Distribution Transformers
}

\author{
Zulfatri Aini' $^{1}$, Zainal Ahnur ${ }^{2}$, David Setiawan ${ }^{3}$, Ahmad Fudholi ${ }^{4}$ \\ ${ }^{1,2}$ Department of Electrical Engineering, Faculty of Science and Technology, Universitas Islam Negeri Sultan Syarif \\ Kasim, Pekanbaru Riau, Indonesia \\ ${ }^{3}$ Electrical Engineering, University of Lancang Kuning, Indonesia \\ ${ }^{4}$ Solar Energy Research Institute, Universiti Kebangsaan Malaysia, Malaysia
}

\begin{tabular}{l}
\hline \hline Article Info \\
\hline Article history: \\
Received Jan 23, 2018 \\
Revised Jul 3, 2018 \\
Accepted Aug 6, 2018 \\
\hline
\end{tabular}

Keyword:

Power system

Transformer

\begin{abstract}
Non-linear loads on power systems cause harmonics and losses in distribution transformers. Results of the measurements on the two distribution transformers showed several phase transformer test-driven development (TDD) values above the standard SPLN D5.004-1: 2012. The values were $5.58 \%$ in the phase transformer, $\mathrm{T} 1$ and $5.48 \%$ and $6.10 \%$ in $\mathrm{S}$ and $\mathrm{T}$ phases of the second transformer, respectively. In the calculations, the transformer losses due to harmonic currents were $1.64 \mathrm{~kW}$ in the phase transformer $\mathrm{T} 1$, and $1.64 \mathrm{~kW}$ and $1.82 \mathrm{~kW}$ in the $\mathrm{S}$ and $\mathrm{T}$ phases of transformer 2, respectively. Designing a single-tuned passive filter based on the characteristics of the current, voltage, power, and power factor in the phase transformer with a value above the TDD standard can reduce the harmonics and losses. A filter with different specifications in each filtered phase transformer was obtained. The filter reduced the TDD value on the phase transformer $\mathrm{T} 1$ to $3.55 \%$ and to $3.88 \%$ and $3.43 \%$ on the on phase $\mathrm{T}$ and $\mathrm{S}$ phases of transformer 2. Moreover, it reduced the losses to $0.73 \mathrm{~kW}$ on phase transformer T 1 , and $1.02 \mathrm{~kW}$ and $0.92 \mathrm{~kW}$ on the $\mathrm{S}$ and $\mathrm{T}$ phases of transformer 2 .
\end{abstract}

Copyright $(2018$ Institute of Advanced Engineering and Science. All rights reserved.

\author{
Corresponding Author: \\ Zulfatri Aini, \\ Department of Electrical Engineering, \\ Faculty of Science and Technology, \\ Universitas Islam Negeri Sultan Syarif Kasim (UIN Suska) 28293, Pekanbaru Riau, Indonesia. \\ Email: zulfatri_aini@yahoo.com
}

\section{INTRODUCTION}

Power quality disturbances, such as voltage sag and harmonic distortion, have increased in the past few decades. One of the factors that cause decline in the quality of electrical power distribution is the use of electric utilities that are non-linearly loaded. Non-linear load causes the emergence of harmonics on the power system. Harmonics cause a deviation in the frequency current or voltage, which is an important aspect in determining the quality of the electric power [1-5]. Determine the number of harmonics generated by the nonlinear load in the residential, commercial and office loads in the feeder distribution and the usefulness of energy due to the harmonic. Natural modelling techniques that model non-linear loads are Norton equations. Harmonic equations harmonic equations models are used from the most accurate devices generated from the experiments. A distribution feed of $20 \mathrm{kV} / 400 \mathrm{~V}$ district to analyze from the nonlinear load at distortion level and harmonic loss. The initialization model is "bottom-up", starting from Norton end user device and then modelling residential, commercial and office load. The result of the harmonic distortion in the Distribution system can increase power by up to $20 \%$ [6]. The concept of improving the quality of power reduces harmonic distortion with a power distribution system consisting of a balanced and unbalanced non-linear load type. Improved power quality using dual active power filter (APF's) in grid-connected distributed generation 
scheme. Active power filters effectively produce compensated signals for harmonic elimination and APF to compensate for the current to be inducted into the distribution network for harmonic elimination under balanced and unbalanced non-linear load conditions. APF is controlled using instant P-Q theory and DG inverters are controlled using a simple control strategy. The proposed system was developed and the results were obtained using MATLAB / SIMULINK software [7].

Distribution transformer is a device in the power system that is directly affected by harmonics. Harmonics in the distribution transformer increase power loss (losses), which reduces transformer performance [8]. To overcome these problems, a filter is installed to reduce harmonics. The filter used is a single-tuned passive filter. Single-tuned passive filters are low-cost filters, which help improve the power factor and compensate the reactive power [9]. The transformers used in the study are two 3-phase distribution transformers of $400 \mathrm{kVA}$ (Faculty of Engineering, University of Riau). Transformer 1 has a phase (T) with a current harmonic value above the standard. Transformer 2 has two phases, namely, phases $\mathrm{S}$ and $\mathrm{T}$.

\section{THEORETICAL AND RESEARCH METHOD}

Harmonics is a disorder that occurs in power distribution systems because of current and voltage waveform distortions. Current and voltage waveform distortions are caused by the formation of waves with frequency integer multiples of the fundamental frequency [10].

The ratio of each component of the harmonic frequency of the fundamental frequency $(50 \mathrm{~Hz})$ is an n-order harmonic, which is defined as [11]:

$$
h=\frac{f_{h}}{f}
$$

where $h$ is the order (order harmonics), $f_{h}$ is the nth harmonic frequency, $f$ is the fundamental frequency $(50 \mathrm{~Hz})$. Harmonic wave is the wave of the $2^{\text {nd }}$ to the h-order. The wave with a fundamental frequency $(50 \mathrm{~Hz})$ is not a harmonic wave. Harmonics arise because of the non-linear loads connected to the distribution system. A non-linear load is an electronic device with many semiconductor components, which act as the switch that works of any wave cycle of the voltage source in the working process. The effects of harmonics are as follows: (i) excessive heat production, which damages the insulation; (ii) malfunction of the labor power equipment, control systems, and energy measurement tools; (iii) reduction in the power rating (derating) of transformers; (iv) reduction in the power factor; and (v) shrinkage of the network [10]. Total harmonic distortion (THD) is the ratio of the value of the current or voltage harmonic components to the value of the current or voltage on the frequency base, and is usually calculated in percentages [9].

$$
T H D=\frac{\sqrt{\sum_{h>1}^{h_{\max }} M_{h}{ }^{2}}}{M_{1}} \times 100 \%
$$

where THD is the total harmonic distortion (\%), $M_{h}$ is the RMS value of the current or voltage harmonic $\mathrm{h}$ (A or $\mathrm{V}$ ), and $M_{l}$ is the RMS value of the current or voltage at the fundamental frequency (A or V). Individual harmonic distortion (IHD) is the ratio of the value of the current or voltage of individual harmonics to the fundamental value of the current or voltage [9].

and

$$
I H D_{i}=\sqrt{\frac{I_{s h}{ }^{2}}{I_{1}{ }^{2}}} \times 100 \%
$$

$$
I H D_{v}=\sqrt{\frac{V_{s h}^{2}}{V_{1}^{2}}} \times 100 \%
$$

where $I H D_{i}$ is the individual harmonic current distortion $(\%), I H D v$ is the individual voltage harmonic distortion $(\%), I_{s h}$ is the harmonic currents of $\mathrm{h}(\mathrm{A}), V_{s h}$ is the voltage harmonics of $\mathrm{h}(\mathrm{V}), I_{l}$ is the fundamental current $(\mathrm{A})$, and $V_{l}$ is the fundamental voltage $(\mathrm{A})$.

Some analysts try to avoid difficulties by finding the THD at the peak load current fundamental frequency rather than the instantaneous sample at the fundamental frequency, which is called the total 
demand distortion (TDD). TDD is included in the standard IEEE 519-1992, in the "Recommended Practices and Requirements for Harmonic Control in Electrical Power System" and SPLN D5.004-1: 2012. The TDD value can be defined as [9]:

$$
T D D=\frac{\sqrt{\sum_{h=2}^{h_{\max }} I_{h}{ }^{2}}}{I_{L}} \times 100 \%
$$

where $I_{h}$ is the harmonic current order, $I_{L}$ is the maximum load current at the fundamental frequency at the point of common coupling (PCC).

IL can be measured in two ways. First, the burden that has been installed in the system is determined, and then the average value of the maximum load current of the previous twelve months is calculated. Second, IL is estimated in the new system based on the load profile that will be installed. The IL value can be determined by the following equation [12]:

$$
I_{L}=\frac{k W}{P F \sqrt{3} k V}(\mathrm{~A})
$$

where $k W$ is the average power demand, $P F$ is the power factor, and $k V$ is the line to line voltage at PCC. The three-phase short circuit at the PCC can be determined by the following equation [9]:

$$
I_{s c}=\frac{1000 \times M V A}{\sqrt{3} k V}(\mathrm{~A})
$$

where $M V A$ and $k V$ represent the three-phase short circuit capacity in the megavolt ampere and the voltage line-to-line at PCC, respectively.

One of the parameters that affect the performance of the distribution transformer is the power loss (losses). Losses may arise because of harmonic distortions. The copper losses in the distribution transformer caused by harmonics can be expressed as follows [9]:

$$
P_{c u}=\sum_{h=1}^{h_{\max }} I_{h}^{2}
$$

where $P_{c u}$ is the copper losses (pu), $h$ is the harmonic order (pu), and $I_{h}$ is the current order (A). follows [9]:

Increased iron losses in the transformers caused by the harmonic distribution can be expressed as

$$
\begin{aligned}
& P_{e}=\left(\sum_{h}^{h_{\max }} I_{h}^{2} x h^{2}\right) \cdot P_{E C-R}
\end{aligned}
$$

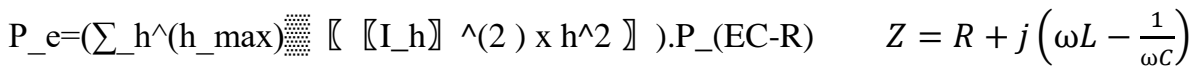

where $Z$ is the impedance of the single-tuned filter $(\Omega), R$ is the resistance $(\Omega), L$ is the inductance $(\mathrm{H})$, and $C$ is the capacitance $(\mathrm{F})$. The stages in this study are as shown in Figure 1. 


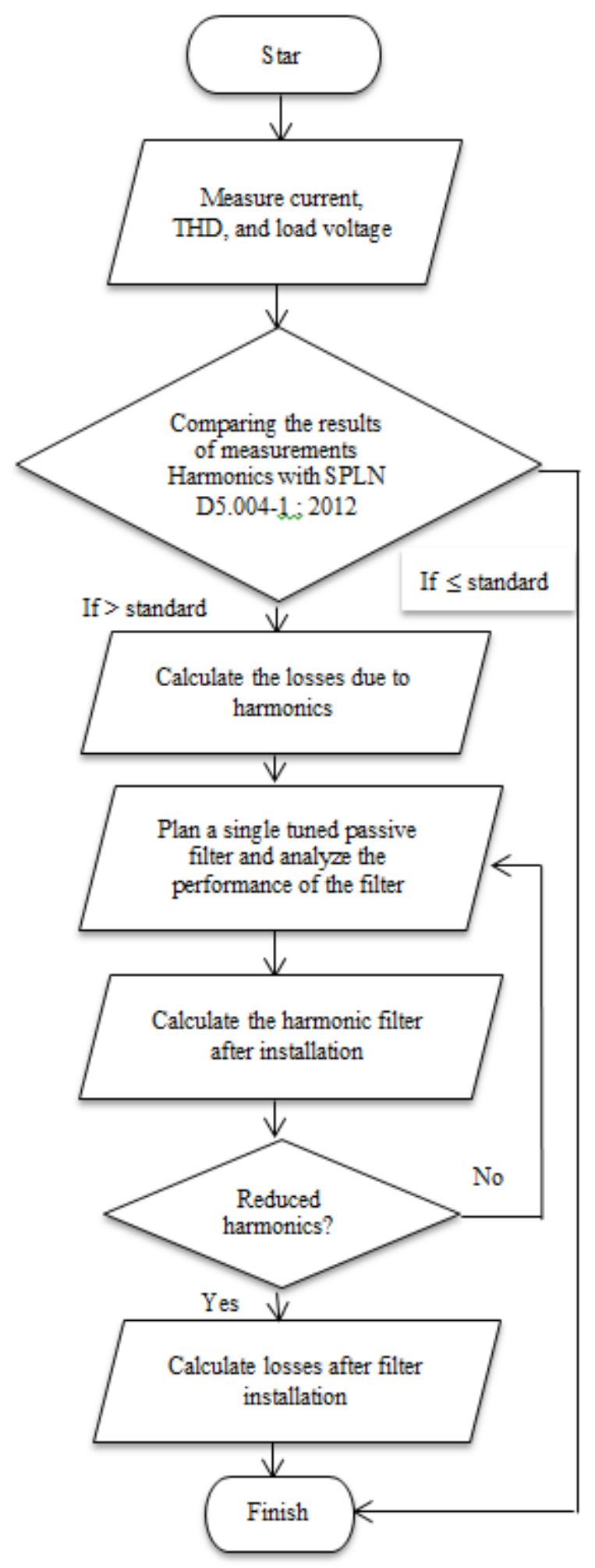

Figure 1. Flowchart research

\section{RESULTS AND DISCUSSION}

The ratio of $\mathrm{I}_{\mathrm{sc}} / \mathrm{I}_{\mathrm{L}}$ on the transformer was equal to 8.21. Therefore, based on SPLN D5.004-1: 2012, $\mathrm{I}_{\mathrm{sc}} / \mathrm{I}_{\mathrm{L}}=<20, \mathrm{I}_{\mathrm{sc}} / \mathrm{I}_{\mathrm{L}}=<20, \mathrm{TDD}_{\max }=5.0 \%, \mathrm{~h}<11=4.0 \%, 11 \leq \mathrm{h} \leq 17=2.0 \%, 17 \leq \mathrm{h} \leq 23=1.5 \%, 23 \leq \mathrm{h}$ $\leq 25=0.6 \%$, and $35 \leq \mathrm{h}=0.3 \%$ were used as the basis of comparison. 
Filters were designed based on the electrical characteristics of the phase transformer harmonic current value that exceeds the standards and the tuned harmonic order. In this study, the phases, which have values above the standard TDD, were referred to as the phase transformer $\mathrm{T} 1$, Transformer $\mathrm{S}$ phase 2 , and phase $\mathrm{T}$ Transformer 2 with harmonic orders of 3, 5, and 3, respectively. The sample calculations to determine the filter specification of the phase transformer $\mathrm{T} 1$ tuned into the 3rd order are as follows:

1) Determine the amount of the reactive power compensation required [14].

On the basis of the results, the value of the reactive power in the smallest QVAr phase transformer T

1 was $12.7 \mathrm{kVAr}$. The exact value of the reactive power compensation is necessary to search for the magnitude of the power factor improvement.

$$
\begin{aligned}
& \mathrm{pf}_{1} \quad=0.958, \text { so } \varphi=\cos ^{-1} 0.958=16.66^{\circ}, \mathrm{P}=44.60 \mathrm{~kW} \\
& Q_{V A R}=P\left(\tan \varphi_{\text {awal }}-\tan \varphi_{\text {akhir }}\right) \\
& \varphi \quad=\tan ^{-1}\left(\frac{44.60 \tan 16.66-12.7}{44.60}\right), \varphi=0.30^{\circ} \text { and } \mathrm{pf}_{2}=\cos 0.30^{\circ}=0.999
\end{aligned}
$$

To determine the values of the filter capacitance $C$ [9]:

$\mathrm{Q}_{\text {var }}=12,7 \mathrm{kVAr}, \mathrm{V}_{\text {rated }}=220 \mathrm{~V}$ and $\mathrm{f}=50 \mathrm{~Hz}$.

$$
\begin{aligned}
& X_{C}=\frac{V_{\text {rated }}^{2}}{Q_{V A R}}=\frac{220^{2}}{12.7}=3.81 \Omega \\
& C=\frac{1}{(2)(3.14)(50)(3.81)}=0.836 \mathrm{mF}
\end{aligned}
$$

2) To determine the values of the filter inductance $L$ [9]:

$$
\begin{aligned}
& \mathrm{h}=3-(5 \% \times 3)=2.85 \\
& X_{L}=\frac{X_{c}}{h^{2}}=\frac{3.81 \Omega}{2.85^{2}}=0.47 \Omega \\
& L=\frac{0,47 \Omega}{(2)(3.14)(50)}=1.49 \mathrm{mH}
\end{aligned}
$$

The entire filter design specification phase transformer can be seen in Table 1.

Table 1. Specifications of the Single-Tuned Passive Filter Design

\begin{tabular}{ccccc}
\hline \multicolumn{2}{c}{ Object } & Phase T & Phase S T2 & Phase T \\
& & $\mathbf{T 1}$ & & $\mathbf{T}$ \\
\hline Tune to-order & $\mathbf{3}$ & $\mathbf{5}$ & $\mathbf{3}$ \\
& $\mathbf{Q}_{\mathbf{V A R}}$ & $12.7 \mathrm{kVAr}$ & $17.7 \mathrm{kVAr}$ & $12.1 \mathrm{kVAr}$ \\
& $\mathbf{C}$ & $0.836 \mathrm{mF}$ & $0.836 \mathrm{mF}$ & $0.836 \mathrm{mF}$ \\
& $\mathbf{X}_{\mathbf{C}}$ & $3.81 \Omega$ & $3.81 \Omega$ & $3.81 \Omega$ \\
& $\mathbf{L}$ & $1.49 \mathrm{mH}$ & $1.49 \mathrm{mH}$ & $1.49 \mathrm{mH}$ \\
& $\mathbf{X}_{\mathbf{L}}$ & $0.47 \Omega$ & $0.47 \Omega$ & $0.47 \Omega$ \\
& $\mathbf{R}$ & $5.87 \mathrm{~m} \Omega$ & $5.87 \mathrm{~m} \Omega$ & $5.87 \mathrm{~m} \Omega$ \\
\hline
\end{tabular}

To determine whether to use the designed filter or not, its obtained value must be compared with the employment limitations. The example calculation of the restricted filter work on phase transformer $\mathrm{T} 1$ is as follows:

1) Analysis of fundamental filter [9]

Fundamental impedance: $X_{\text {fund }}=|0.47-3.81|=3.34 \Omega$

Fundamental current:

$I_{\text {fund }}=\frac{223.3 \mathrm{~V}}{3.34 \Omega}=66.86 \mathrm{~A}$

with $\mathrm{V}=223.3 \mathrm{~V}$ value of the measurement results. 
Voltage capacitor: $V_{C}=66.86 \mathrm{~A} \times 3.81 \Omega=254.74 \mathrm{~V}$

Rating capacitor:

$$
Q_{\text {fund }}=254.74 \mathrm{~V} \times 66.86 \mathrm{~A}=16.78 \mathrm{kVAr}
$$

2) Analysis work on the harmonic filter [9]

Total current harmonic filter: $I_{\text {Total }}=0.1515 \times \frac{13.3 \mathrm{kVAr}}{220 \mathrm{~V}}=9.16 \mathrm{~A}$

Harmonic voltage capacitor: $V_{c h}=\frac{9.16 \mathrm{~A} \times 3.81 \Omega}{3}=11.63 \mathrm{~V}$

3) Calculation of total labor filter [9]

RMS current total: $I_{r m s}=\sqrt{66.86^{2}+9.16^{2}}=67.48 \mathrm{~A}$

Peak voltage: $V=254.74+11.63=266.37 \mathrm{~V}$

RMS voltage: $V_{r m s}=\sqrt{254.74^{2}+11.63^{2}}=255.00 \mathrm{~V}$

Total reactive power capacitors $\left(\mathrm{Qc}_{\text {total }}\right): \mathrm{Qc}_{\text {total }}=67.48 \mathrm{~A} \times 255.00 \mathrm{~V}=17.20 \mathrm{kVAr}$

The comparison of the results of all the phase transformers can be seen in Table 2.

Tables 2. Comparative Results of the Filter Work Limitation [9]

\begin{tabular}{|c|c|c|c|c|c|}
\hline \multicolumn{2}{|l|}{ Work } & Peak voltage & $\begin{array}{c}\text { RMS } \\
\text { voltage }\end{array}$ & $\begin{array}{c}\text { RMS } \\
\text { current }\end{array}$ & $\begin{array}{c}\text { Power } \\
\text { capacitors }\end{array}$ \\
\hline \multirow{2}{*}{\multicolumn{2}{|c|}{ Definition }} & V & $V_{r m s}$ & $V_{r m s}$ & $Q c_{\text {total }}$ \\
\hline & & $\overline{V_{\text {rated }}}$ & $\overline{V_{\text {rated }}}$ & $\overline{V_{\text {rated }}}$ & $\overline{Q_{\text {fund }}}$ \\
\hline \multicolumn{2}{|l|}{ Limit (\%) } & 120 & 110 & 180 & 135 \\
\hline \multirow{4}{*}{$\begin{array}{l}\text { Actual filter } \\
\text { value }\end{array}$} & $\mathrm{T} 1$ & $266.37 \mathrm{~V}$ & $255.00 \mathrm{~V}$ & $67.48 \mathrm{~A}$ & $17.20 \mathrm{kVAr}$ \\
\hline & $\begin{array}{c}\text { Phase } \mathrm{T} \\
\mathrm{T} 2\end{array}$ & $\begin{array}{r}231 \mathrm{~V} \\
241.55 \mathrm{~V}\end{array}$ & $\begin{array}{c}231 \mathrm{~V} \\
234.29 \mathrm{~V}\end{array}$ & $\begin{array}{l}\overline{66.86 A} \\
86.83 A\end{array}$ & $\begin{array}{l}\overline{17.03 \mathrm{kVAr}} \\
20.34 \mathrm{kVAr}\end{array}$ \\
\hline & $\begin{array}{c}\text { Phase } S \\
\text { T2 }\end{array}$ & $\begin{array}{c}\overline{231 \mathrm{~V}} \\
268.28 \mathrm{~V}\end{array}$ & $\begin{array}{c}231 \mathrm{~V} \\
254.63 \mathrm{~V}\end{array}$ & $\begin{array}{l}\overline{85.78 A} \\
64.53 \mathrm{~A}\end{array}$ & $\begin{array}{l}\overline{20.09 \mathrm{kVAr}} \\
16.43 \mathrm{kVAr}\end{array}$ \\
\hline & Phase T & $\overline{231 \mathrm{~V}}$ & $\overline{231 \mathrm{~V}}$ & $\overline{63.56 \mathrm{~A}}$ & $\overline{16.16 \mathrm{kVAr}}$ \\
\hline \multirow{3}{*}{$\begin{array}{l}\text { Actual filter } \\
\text { value }(\%)\end{array}$} & $\begin{array}{c}\text { T1 } \\
\text { Phase T }\end{array}$ & 115.31 & 110.38 & 100.93 & 101.00 \\
\hline & $\begin{array}{c}\text { T2 } \\
\text { Phase S }\end{array}$ & 104.57 & 101.42 & 101.22 & 101.24 \\
\hline & $\begin{array}{c}\text { T2 } \\
\text { Phase T }\end{array}$ & 116.14 & 110.23 & 101.53 & 101.67 \\
\hline
\end{tabular}

The results showed that no work amount exceeded the standard set.

The harmonic current absorbed by the filter reduced the value of the TDD on the transformer, which owns the parameters that measure the current harmonics. The unfiltered current TDD value was obtained from direct measurement using a power quality analyzer. The filtered TDD was calculated based on equation (5). The current value after filtering in-phase transformers $\mathrm{T} 1$ is calculated as follows:

The short-circuit impedance of the system $(\Omega)[9]$ :

$$
\begin{aligned}
Z_{h s} & =\frac{k V \times 1000}{I_{s c}} \\
Z_{h s} & =\frac{0.4 k V \times 1000}{\sqrt{3} \times 577.4 \mathrm{~A}}=0.4 \Omega
\end{aligned}
$$

Short circuit reactance of the system $(\Omega)[9]$ :

$$
X_{h s}=X_{h s t}=Z \% \frac{k V^{2}}{M V A}
$$




$$
X_{h s}=0.04 \times \frac{400^{2} V}{400 k V A}=0.016 \Omega
$$

System short circuit resistance value $(\Omega)$ :

$$
R_{h s}=\sqrt{Z_{h s}^{2}-X_{h s t}^{2}}=\sqrt{(0.4)^{2}-(0.016)^{2}} \Omega=0.4 \Omega
$$

To calculate the filtered value of the reactance $\mathrm{L}$ and $\mathrm{C}$ in order harmonics:

The reactance $\mathrm{L}$ in order harmonics- 3 is calculated as follows:

$$
X_{L(3)}=3 \times 0.4 \Omega=1.41 \Omega
$$

The value of $\mathrm{C}$ is $X_{C(3)}=\frac{3,81 \Omega}{3}=1.27 \Omega$

To calculate the value of the short circuit resistance and reactance- 3 in the harmonic order:

Resistance value $R_{h s(1)}=R_{h s(3)}=0.4 \Omega$, while the short circuit reactance in the harmonic 3rd-order transformer is as follows:

$$
X_{\text {hst }(3)}=3 \times 0.016 \Omega=0.048 \Omega
$$

The value of the short circuit impedance $\mathrm{Z}$ system on 3rd-order harmonics is calculated as follows:

$$
Z_{h s(3)}=\sqrt{(0.4)^{2}+0.048^{2}} \Omega=0.4 \Omega
$$

Calculate the total value of harmonic currents of the 3rd filter, with the 3rd harmonic current order of $8.44 \mathrm{~A}$ :

$$
I_{f(3)}=\frac{0.4 \Omega}{0.4 \Omega+|1.41 \Omega-1.27 \Omega|} \times 8.44 A=6.25 A
$$

The harmonic currents on the 3rd order after the installation of the filter is

$$
I_{3(\text { new })}=(8.44-6.25) A=2.19 A
$$

The current and TDD transformer on another phase can be seen in Table 3.

Tables 3. Current Value and TDD Transformers Before and After the Filter Installation

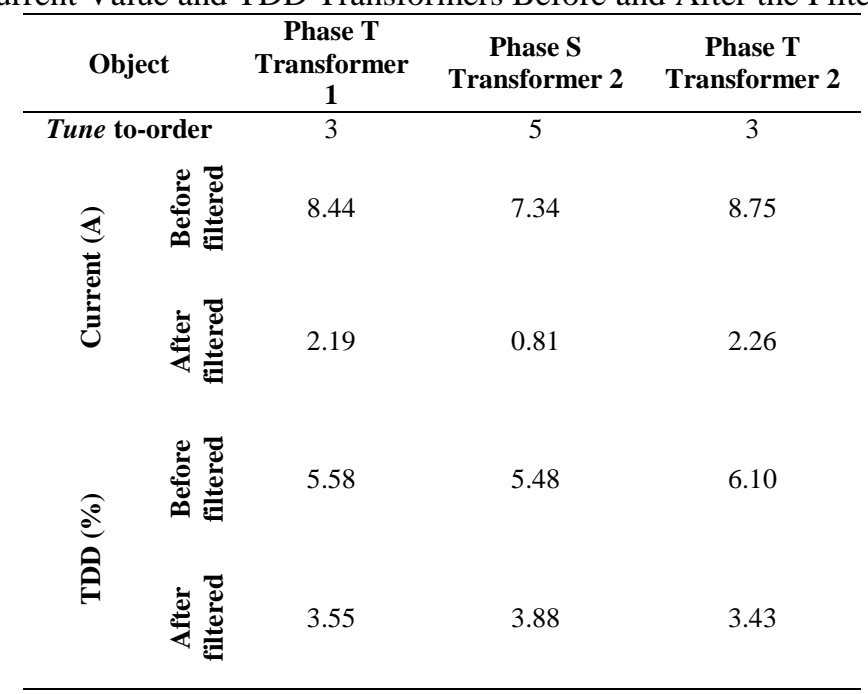

The calculation of transformer losses caused by harmonics filter installation is the same as the calculation of the losses before the installation of the filter. The losses will be reduced by the reduced current harmonic filter that was designed based on the orders described previously. 
In addition to reducing the order harmonics, the single-tuned passive filter mounted in parallel also absorbs power from the system. This will certainly cause filter assembly losses. The magnitude of the losses resulting from the installation of filters on phase transformer $\mathrm{T} 1$ is as follows:

Power absorbed by the filter in phase transformer $\mathrm{T} 1$ :

$$
P=66.86^{2} A \times 0.00587 \Omega=0.026 k W
$$

The $\mathrm{P}$ value is the result of the mounting losses at $66.86 \mathrm{~A}$ filter, a fundamental flow filter, and a $5.87 \mathrm{~m} \Omega$ resistance value filter. The amount of filter with $\mathrm{X}$ fund power factor of $3.34 \Omega$ can be calculated as follows.

$$
Q=66.86^{2} A \times 3.34 \Omega=14.93 \mathrm{kVAr}
$$

Then,

$$
S=\sqrt{0.026^{2}+14.93^{2}}=14.93 k V A
$$

Then, we obtain a power factor in the filter by

$$
p f=\frac{0.026 \mathrm{~kW}}{14.93 \mathrm{kVA}}=0.0017
$$

In the filter phase transformer $\mathrm{T} 1$, the reactive power of $12.7 \mathrm{kVAr}$ is the power capacitor used to compensate the reactive power in the system. Therefore, the losses in the filter are as follows:

Consequence of losses filter $=\left(\sqrt{(14.93 k V A r-12.70 k V A r)^{2}+(0.026 k W)^{2}}\right) \times(0.0017)=$ $0.0038 \mathrm{~kW}$

The losses caused by harmonic filter after installation is as follows:

$\mathrm{S}=2 \times 400 \mathrm{kVA}=800 \mathrm{kVA}$. The power factor or the average power factor of the second transformer = 0.927

The power $\left(\mathrm{P}_{\text {base }}\right)$ of the first phase is calculated as follows:

$$
\begin{aligned}
P_{\text {base }} & =\frac{S \times \text { Faktor Daya }}{\sqrt{3}} \\
P_{\text {base }} & =\frac{800 \mathrm{kVA} \times 0.927}{\sqrt{3}}=428.16 \mathrm{~kW}
\end{aligned}
$$

Therefore, on the basis of equations (8) and (9), the losses in transformers caused by the harmonic filter after installation is:

$$
\begin{aligned}
& P_{L L}(p u)=(0.0007)+(0.0967)(0.01)=0.0017 \mathrm{pu} \\
& P_{L L}(k W)=P_{\text {base }} \times 0.0017 \mathrm{pu} \\
& P_{L L}=428.16 \mathrm{~kW} \times 0.0017=0.73 \mathrm{~kW}
\end{aligned}
$$

Each phase of the losses in the transformer can be seen in Table 4. It shows that using one single-tuned passive filter in each phase can considerably reduce the losses.

Tables 4. Transformer Losses Caused by Harmonics

\begin{tabular}{lccc}
\hline Object & $\begin{array}{c}\text { Losses resulting } \\
\text { filter installation }\end{array}$ & \multicolumn{2}{c}{ Losses value } \\
& & Before & After \\
filtered & filtered \\
\hline Phase T transformer 1 & $0.0038 \mathrm{~kW}$ & $1.64 \mathrm{~kW}$ & $0.73 \mathrm{~kW}$ \\
Phase S transformer 2 & $0.0085 \mathrm{~kW}$ & $1.64 \mathrm{~kW}$ & $1.01 \mathrm{~kW}$ \\
Phase T transformer 2 & $0.0037 \mathrm{~kW}$ & $1.82 \mathrm{~kW}$ & $0.90 \mathrm{~kW}$ \\
\hline
\end{tabular}




\section{CONCLUSION}

Based on the results of this study, the following conclusions were formed:

1 Not all phase transformers have values above the standard TDD.

2 Installing a filter on each phase with a value of TDD over the standard system can improve the power factor of the phase to 0.999 .

3 The specification of each filter on the filtered phase difference is caused by the characteristics of each filtered phase.

4 The value of the losses caused by harmonics in the transformer $\mathrm{T} 1$ phase after the installation of the filter units was reduced from $1.64 \mathrm{~kW}$ to $0.73 \mathrm{~kW}$. In phases $\mathrm{S}$ and $\mathrm{T}$ of transformer 2 , the losses after the installation of one filter on each phase decreased from $1.64 \mathrm{~kW}$ and $1.82 \mathrm{~kW}$ to $1.02 \mathrm{~kW}$ and 0.90 $\mathrm{kW}$, respectively.

\section{ACKNOWLEDGEMENTS} 2017-045).

The authors would like to thank the UKM and UIN Suska Riau for funding (GP-K020448) and (GGP-

\section{REFERENCES}

[1] M. Farhoodnea, et al. "Power quality improvement in distribution systems considering optimum D-STATCOM placement (Peningkatan Kualiti Kuasa dalam Sistem Pengagihan Berdasarkan Penempatan D-STATCOM Optimum”. Jurnal kejuruteraan 25: 11-18, 2013.

[2] M. Farhoodnea, et al. "Optimum active power conditioner placement for power quality enhancement using discrete firefly algorithm". Proceedings of the World Congress on Engineering and Computer Science 2013 Vol I WCECS 2013, 23-25 October, 2013, San Francisco, USA.

[3] M. Farhoodnea, et al. "Power quality impact of renewable energy based generators and electric vehicles on distribution systems". Procedia Technology 11: 11-17, 2013.

[4] M. Farhoodnea, et al. "Power quality impact of grid-connected photovoltaic generation system in distribution networks". 2012 IEEE Student Confrence on Research and Development:1-6.

[5] A. Kazemi, et al., et al. "A review of power quality monitor placement methods in transmission and distribution systems”. PRZEGLĄD ELEKTROTECHNICZNY R.89: 185-188, 2013.

[6] M.J. Ghorbani and H. Mokhtari, "Impact of harmonics on power quality and losses in power distribution systems". International Journal of Electrical and Computer Engineering (IJECE) 5(1): 166-174, 2015.

[7] M.J. Ghorbani and H. Mokhtari, "Impact of harmonics on power quality and losses in power distribution systems". Indonesian Journal of Electrical Engineering and Computer Science 7(2): 322-337, 2017.

[8] D.M. Said, dan K.M Noer. "Effects of harmonics on distribution transformers". Australasian Universities Power Engineering Conference 107: 1-5, 2008.

[9] Roger C Dugan, Electrical Power System Quality. New York: McGraw-Hill, 2004.

[10] PT. PLN (Persero), Buku Program Mutu Produk. II. Jawa Timur: PT. PLN (Persero) Distribusi Jawa Timur, 2013.

[11] Abdul Kadir, Transformator. Jakarta: Universitas Indonesia, 2010.

[12] J Arrilaga, et al., Power System Harmonics. New York: John Wiley \& Sons, 2003.

[13] J.C. Das, "Passive Filters - Potentialities and Limitations". IEEE Transactions on Industry Applications Vol. 40 No.1: $232-241,2004$

[14] Hari Prasetijo, "Analisa Perancangan Filter Pasif Untuk Meredam Harmonik Pada Instalasi Beban Nonlinear". Techno ISSN 1410 - 8607 Vol. 13 No. 1: 57 - 56, 2012.

\section{BIOGRAPHIES OF AUTHORS}

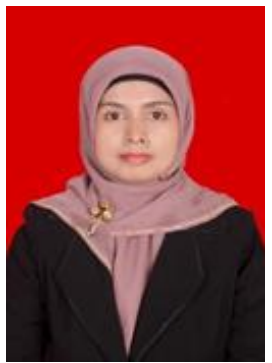

Zulfatri Aini, S.T., MT, obtained her S.T (1996) in Electrical Engineering. She has worked experience about 5 years (2000-2005) as Lecturer at Sekolah Tinggi Teknik Padang, Indonesia, and (2006-until Now) as Lecturer at Electrical Engineering, Faculty of Sains and Technology, Universitas Sultan Syarif Kasim, Riau, Indonesia. Aini started her master course in Electrical Power System (2003-2005) at Universitas Gadjah Mada (UGM). After her master she became at Sekolah tinggi Teknik Padang as Lecturer up to 2006, and then Currently is candidate Dr (Ph.D) in Universitas Negeri Padang (UNP), Padang. Her current research focuses on Power System, Power Electronic and Energy Audit, especially. 

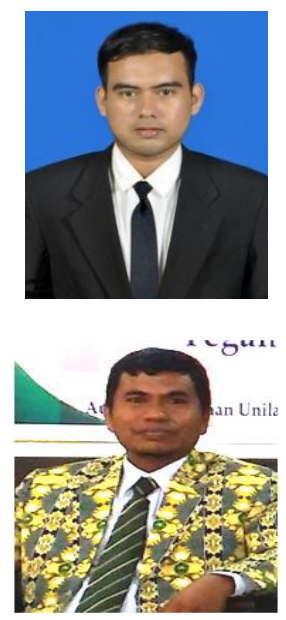

David Setiawan, ST., MT. obtained S.T.(2003) in electrical engineering. He was worked experience about 6 years (2004-2010) as adjunct lecturer and permanent lecturer since 2010 until now at University of Lancang Kuning Pekanbaru, Riau, Indonesia. D. Setiawan started his master course in electrical engineering/power system engineering (2005-2008) at Sepuluh Nopember Institute of Technologi, Surabaya, Indonesia. His current research focuses on renewable energy and control systems

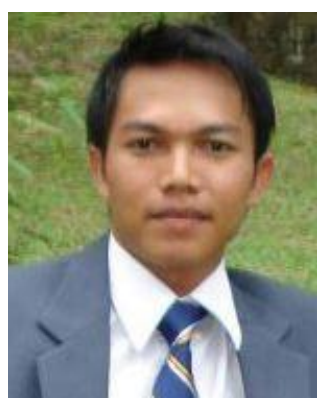

Ahmad Fudholi, Ph.D, M.Sc, S.Si obtained his S.Si (2002) in physics. He was born in 1980 in Pekanbaru, Indonesia. He has working experience about 4 years (2004-2008) as Head of Physics Department at Rab University Pekanbaru, Riau, Indonesia. A. Fudholi started his master course in Energy Technology (2005-2007) at Universiti Kebangsaan Malaysia (UKM). His M.Sc thesis was on Wind/PV Hybrid System and the Ph.D thesis was about the Finned Double-Pass Solar Collectors for Drying of Seaweed. His M.Sc and Ph.D thesis under supervisor by Prof Dato' Dr. Kamaruzzaman Sopian. After his master he became Research Assistant at UKM up to 2012. After his Ph.D (2012) in renewable energy, he became Postdoctoral in Solar Energy Research Institute (SERI) UKM up to 2013. He joined the SERI as a Lecture in 2014. More than USD 310,000 research grant (15 grant/ project) in 2014-2017 was involved. More than $25 \mathrm{M}$.Sc project supervised and completed. Until now, he managed to supervise $5 \mathrm{Ph} . \mathrm{D}$ (4 main supervisors and 1 Co. supervisor), 3 Master's student by research mode, and 5 Master's student by coursework mode, he was also as examiner ( $3 \mathrm{Ph} . \mathrm{D}$ and $1 \mathrm{M} . \mathrm{Sc}$ ). His current research focuses on renewable energy, especially solar energy technology, micropower system, solar drying systems, and advanced solar thermal systems (solar assisted drying, solar heat pump, PVT systems). He has published more than 120 peer-reviewed papers, which 25 papers in ISI index (20 Q1, impact factor more than 3) and more than 60 papers in Scopus index, 16 more currently accepted manuscript, 20 more currently under review, and 2 book chapters. Addition, he has published more than 70 papers in international conferences. His total citations of 810 and hindex of 14 in Scopus (Author ID: 57195432490). His total citations of 1387 and h-index of 20 in google scholar. He is appointed as reviewer of high impact (Q1) journal such as Renewable and Sustainable Energy Reviews, Energy Conversion and Management, Applied Energy, Energy and Buildings, Applied Thermal Engineering, Energy, Industrial Crops and Products, etc. He is appointed as reviewer of reputation journals such as Drying Technology, International Journal of Green Energy, Biosystem Engineering, Journal of Sustainability Science and Management, Journal of Energy Efficiency, Sains Malaysiana, Jurnal Teknologi etc. He is also appointed as editor journals. He has received several awards such as Gold Medal Award at the International Ibn Al-Haytham's Al-Manazir Innovation and Invention Exhibition 2011, Silver Medal Award at the International Technology EXPO (ITEX) 2012, Silver Medal Award at the Malaysia Technology Expo (MTE) 2013, Bronze Medal Award at International Exposition of Research and Invention (PECIPTA) 2011, also 2 Bronze Medal Award at PECIPTA 2017. He was also invited as speaker: Workshop of Scientific Journal Writing; Writing Scientific Papers Steps Towards Successful Publish in High Impact (Q1) Journals. He has 1 patent and 2 copyrights. 